\title{
Influence of Social Media on Brand Positioning and Brand Equity: A Study on Fast Moving Consumer Goods of Bangladesh
}

\author{
Trina Saha ${ }^{1 *}$ Nirjhar Kumar ${ }^{2} \quad$ Fatema Jannat $^{1} \quad$ Nazmoon Nahar $^{3}$ \\ 1. Assistant Professor, Department of Business Administration, Noakhali Science \& Technology University, \\ PO Box No-3814, Sonapur, Noakhali, Bangladesh \\ 2. Marketing Manager, Fanfare Bangladesh Ltd., Dhaka, Bangladesh \\ 3. Lecturer, Balakhal Maqbul Ahmed Degree College, Bangladesh
}

\begin{abstract}
Today social media is not just a tool of passing time, it is big marketing tool to speak directly with existing and potential customers. It helps to increase brand value with the engagement of a large number of audience. This research is based on the relationship among social media, brand positioning and brand equity. The key factors of branding are brand awareness, brand loyalty, perceived quality, brand image, brand equity etc. The analyses are based on survey data which have been collected through online and offlin Ne survey from 250 respondents who are using social media platform for their buying decisions of Fast Moving Consumer Goods such as food and beverages, household goods and personal care products. We used several statistical techniques to find out the impact of independent variable on dependent variable. The results of our study showed that there is positive relationship among social media and brand positioning and brand equity. On the basis of our results it can be suggested that companies should invest more in social media marketing if they don't want to miss a super-fast inexpensive and also an effective way to reach a huge customer base.
\end{abstract}

Keywords: Social Media, Social Media Marketing ,Brand Equity, Brand Positioning.

DOI: $10.7176 / \mathrm{EJBM} / 13-6-12$

Publication date:March $31^{\text {st }} 2021$

\section{Introduction}

Since the late 1990s , people are communicating themselves through social media, actually they have become social media themselves. Social media is the catchphrase of today's business world, no one can ignore its influence on physical world. Social media is a phenomenon that has drawn a lot of attention both to companies and individuals interacting on the networking landscape. It is changing traditional marketing communications. Traditional brand communications that were previously controlled and administered by brand and marketing managers. Today thorough social media network consumers can directly interact with brands and brands can also know their consumers better than before.

Before purchasing anything a consumer always try to know some brands or recall a brand if he is aware of a product category and a brand within that category. Social media is a playground with a ton of people which can increase the potentiality of building brand awareness among consumers. It also offers new opportunities to attract new consumers, attract new customers. Mangold and Faulds (2009) illustrated in their study that consumers will tell seven to ten individuals about the product and their satisfaction, but now social media permits consumers to share experiences with other customers in no time. Social sites also work as a search engine which makes it easy to find conversations about an industry, products or services. It is easy to grab new market here as it uses images and videos which attract the target audience.

\section{Literature Review}

\subsection{Social Media}

Neti (2011) in her article of social media and marketing, defined social media as any website where users can share their opinions, views, interact with others to build community. She explained the term social as communication and interaction of individuals within a group or community and media as advertising where ideas or information are communicated via different channels. In their study Kaplan \& Haenlein (2010) viewed social media as a group of applications powered on the internet and divided social media into several dimensions including blogs, virtual worlds, social networking sites which can be used for social media advertising. Mangold and Faulds ( 2009) in their study of social media and promotion mix explained it as a way of communication where users can easily interact with each other. It has changed the way of communication approach and customer connection. Blackshaw and Nazzaro (2004) described it as new source of online information that are created , interacted used by consumers who are willing to know about products, brands, personalities, services etc.

\subsection{Social Media Marketing}

McKinsey (2007) in his study of global survey explained that businesses are using social media marketing as marketing strategy to be engaged with online based consumer network. He defined it as instruments of 
communication with customers, direct sales activities, customer attainment and customer retaining.In their study Kim and Ko (2012) found that marketers are using social media as way of interactive communication to enhance their existing relationship with consumers. They identified several forms of social media marketing such as weblogs, blogging, podcasts, pictures, video etc. Keller (2009) suggested that communication can strengthen dimensions of brand equity such as brand awareness, customer loyalty towards brand. Gordhamer (2009) related social media marketing with relationship marketing because here the firms try to make connections with the consumers rather than trying to sell to them.

\subsection{Brand}

Davis and Bojalil Rébora (2002) defined brand as company's representation of it as an intangible but critical component. Kotler and Keller (2012) recognized it as one of the most valued assets because of their role of influencing the evaluation and buying decision of consumers. As study of brands are placing consumers in the main focus, Brown (1992) explained them as the sum of all the psychological influences people have around it. Wheeler (2012) identified three functions of brands comprising of navigating the consumers to choose brand from various options, providing safety of decision making of the consumers and engaging customers through images and languages .

\subsection{Brand Equity}

Christodoulides and Chernatony (2010) defined brand equity as a complete set of attitudes, knowledge, perceptions and behaviors which increases utility allowing greater earnings than that a brand can enjoy without the brand. Mohsin (2009) suggested communication of values, emotions, lifestyles is must to attain brand equity, he looked brand equity as something more than product name and function. Jakštè \& Kuvykaitè (2016) identified three dimensions of brand equity such as awareness, associations and loyalty. Company's capability of managing communication with consumers have strong impact on social media communication. Alhaddad (2015) suggested to focus on creating awareness on advertising to create brand equity. The author also said that people prefer to remember and recognize visual posts more than other posts.

\subsection{Brand Awareness}

Hoeffler and Keller (2002) illustrated brand awareness from two determinants, one is depth which means the way of easy recalling or identifying brand by the consumers and another is width which means customers remembrance of a brand name at the of purchasing a product. Customer awareness regarding any brand is dependent on the depth and width of its product. Gil, Andre's \& Salinas (2007) identified four different ways of brand awareness. They are creating a brand node in the memory of consumers, providing a sense of familiarity in consumers mind, acting as a signal of trust in the brand and being enough motive for the consumer to consider the brand in his thought. Keller (1998) described social networking sites as a marketing tool to create brand awareness and identified there advantages of these sites such as learning advantages, consideration advantages and choice advantages.

\subsection{Brand Image}

In their study of brand interactions and social media Nisar and Whitehead (2016) said that there are associations between brand image and brand perceptions which may originate from the market offer or direct experiences of customers at the time of purchasing any brand. When a number of brand perceptions are reflected in the customer's memory then the concept of brand image is widely accepted. Alhaddad (2015) found a significant effect of brand awareness and brand image on brand equity. He indicated in his model that brand image has bigger effect on brand equity than advertising awareness and brand awareness and brand awareness and brand image can be enhanced and created by advertising awareness and a positive brand image is helpful to increase competition and for encouraging customers to repeat their purchasing transaction.

\subsection{Brand Loyalty}

Tuominen (1999) explained brand loyalty as a very complex phenomenon that can reflected in the different stages of consumers' mindset - "from the habitual buyer to the satisfied buyer to those that like the brand to the truly committed". Assael (2001) suggested positive attitude and experience as the root of repeat purchase over time that can be the result of multiple confirmations of a brand's ability to meet the needs of the consumers in the best way. Pozin (2014) described social media as a very useful tool for creating and maintaining brand loyalty that can be achieved through managing relationship with the existing customers of the brand. According to Montero (2015), brands can maintain direct conservations and interactions with individuals through social networking sties and brands that are actively maintaining personal interactions by participating conversations on social media may be able to create and strengthen their customers brand loyalty. Ceyhan (2019) found that brand loyalty or purchase intention are not affected by some marketing applications. Despite being successful some marketing application 
did not affect brand loyalty or purchase intention.

\subsection{Perceived Quality}

Aaker (1991) defined perceived quality as a concept of summarizing consumers' opinion about brands functionality, performance perfection, design, supporting services and other features and characteristics. Grubor et al. (2017) suggested companies to emphasize on firm created brand communication through social media if they want to improve perceived quality of its environment friendly brand, because this kind of brand communication is considered to be positive by customers. To achieve perceive quality customers personal evaluation, their likings and sharing content are also important. Schivinski and Dąbrowski (2013) found a positive relationship among social media, brand loyalty and perceived quality and no relationship between social media and brand equity dimensions.

\subsection{Brand Positioning}

Davis (2000) defined positioning as the place in consumers 'mind that a brand wants to own that is externally driven and relevant, need to be differentiated from competition and most importantly needs to be valued. Ellwood (2009) explained the concept brand positioning communication activity as the major area of reference because it has broader market impact and also defined it as external activities which determines the behavior within an organization. Janiszewska and Insch (2012) suggested skillful use of positioning at every stage of management process. They defined it as the answer to the challenges posed by modern branding that allows administrative unit to make informed amendments to the growth strategy in the context of competition and the stakeholders changing needs and expectations.

\section{Research Problem}

Social media as a tool of marketing is not speculation now, it is now reality. Businesses are now creating and sharing content on social media networks in order to achieve organizational branding goals. In Bangladesh, the FMCG industry can be classified in three major categories- Foods and Beverage, Personal Care and Household Care Industries. For their non-durability and frequent consumption FMCG products is are produced, packaged and distributed in massive quantities. The buyer needs little or no time to choose between varieties. Consumers no longer need to constantly head to the nearest retail outlet or super shops. They can simply order them online at shopping websites, that too after analyzing product reviews from a plethora of websites, YouTube and blogs. There are a good number of research on social media marketing but there is insufficiency of research on its influence on brand positioning and brand equity especially in Bangladesh. . So there is a research hole and the purpose of this research is to catch out the impacts of social media on brand positioning and brand equity in the FMCG industry of Bangladesh.

\section{Justification of Research}

There is huge potentials of social media as a tool of marketing in Bangladesh. Using social media for marketing can enables small business to attract more customers. Businesses can measure whether their product or services are getting viral or failure, whether they are doing better than their competitors or not, they can also know whether consumers are talking about other competitors' products or not. Sometimes consumers don't express their true opinion or are not able to express direct to the business. But in social media millions of people make comments about their opinion, so it is an easy platform for them to express their actual feeling about the product or service. Sometimes it works as a helpful ground to find out innovative product uses. Now a days a good number of business entrepreneurs are using social media as their regular marketing tool. If implemented strategically, it can bring huge achievement in Bangladesh. These issues stimulated the present research to be pursued.

\section{Research Methodology}

\subsection{Population and Sample}

The research data were collected from both primary and secondary data. Research population is the consumers of fast moving consumer goods of Bangladesh and target sample size is 250 respondents from Bangladesh who are regular users of several social network sites. Random sampling method was followed without focusing on the background of the respondents including students from different public and private universities of Bangladesh, housewives, professionals, retired persons, businessmen etc. from different areas of Bangladesh who have a good concept about social media and brand.

\subsection{Data Collection Method}

The main mechanism of data collection was questionnaire survey. The questionnaire comprised of three parts. A five point Likert Scale from Strongly Disagree $=1$ to Strongly Agree $=5$, with a set of statements was used in the questionnaire to get the opinions of the respondents. The survey was conducted through online platform and face 
to face questionnaire distribution. On the other hand secondary data was collected from several research papers, internship reports, annual reports of several banks, survey reports etc. Some data was also collected about impact of social media on customer's buying behavior and how they get their needed information about different packages from social media like Facebook, Instragram etc. by primary basis via discussion and observation etc.

\subsection{Variables and Hypothesis Development}

The study is undertaken with the objectives of assessing the pervasiveness of social media as a means of marketing tool in building a strong brand position and creating a platform of increasing brand equity. To achieve these objective and solve the research problem 10 statements representing use of social media in creating strong brand position including product features and benefits, expectations, competitors analysis, price sensitivity, good value proposition, brand name, market trend, packaging, high pricing etc. and and 10 statements representing the use of social media in attaining a strong brand equity such as brand loyalty, customer satisfaction, high cost implications, personality of brand, perceived value, brand association, market behavior, brand switching etc. were selected and hypotheses were developed in the light of the assessments of associated literature. Here we have two dependent variables, one is brand positioning and another one is brand equity and independent variable is social media. We developed one hypothesis for each dependent variable and independent variable. Thus, the following hypotheses were developed:

H1: Social Media has a positive influence on Brand Positioning.

H2: Social Media has a positive influence on Brand Equity.

\subsection{Data Analysis Tools}

Analyses were done through statistical software. The impact of independent variable on dependent variable was tested on the basis of some key factors. The collected data and information were critically analyzed and interpreted by the researchers in order to make the study more informative, exploratory, and useful to the readers. Reliability and factors analysis were done to test the reliability and validity of the study, descriptive statistics were used to analyze the primary data, correlation analysis was done to find out the relationship between dependent and independent variables, and regression analysis was done to find out the impact of independent variable on dependent variable.

\section{Results and Discussions \\ 6.1 Validity Analysis}

Validity analysis is necessary in quantitative research to measure the accuracy of research method. If the results parallel to the real world value then we can consider it as valid. KMO test measure the adequacy of sample. If the value is greater than .7 then we can say the sample size is adequate. Here our results shows a good KMO value i.e.734 indicating sufficient items and signifying the adequacy of sample size. Bartlett's test of sphericity test the null hypothesis to check whether there is redundancy between variables. Here, our chi-square value is1384.236 at with 190 degrees of freedom, which is greater than the table value and significance level is also less than .05 suggesting to reject the null hypothesis that the original correlation matrix is identity matrix. Thus, we can say the Bartlett's test is highly significant.

\begin{tabular}{|l|l|r|}
\hline \multicolumn{2}{|c|}{ Table 1: KMO and Bartlett's Test } \\
\hline Kaiser-Meyer-Olkin Measure of Sampling Adequacy. & .734 \\
\hline \multirow{2}{*}{ Bartlett's Test of Sphericity } & Approx. Chi-Square & 1384.236 \\
\cline { 2 - 3 } & df & 190 \\
\cline { 2 - 3 } & Sig. & .000 \\
\hline
\end{tabular}

\subsection{Demographic Profile}

Although we have sent questionnaire to more than 330 persons but only 250 responded. Thus the response rate is $75.76 \%$. From demographic profile of the survey participants we found the number of male participants is higher than female participants. And most of the participants (70.8\%) fall under the category of young generation as it is true that social media is very popular among them. It also can be seen that about $43.6 \%$ of the total participants are graduate, suggesting that students are very much involved in social media.

\subsection{Testing of hypothesis 1: Social Media has a positive influence on Brand Positioning. 6.3.1 Reliability Analysis}

Reliability or internal consistency of multiple-question likert scale survey is measured by Cronbach's Alpha. General rule of thumb for Cronbrach's alpha is .06-.70 or above is considered good and .80or above is better. Thus our value of .747 suggests that the questionnaire as well as collected data and sample size are reliable from every dimensions. 


\subsubsection{Correlation Analysis}

Correlation Analysis was done to find out the relationship between dependent variable and independent variables. The questions are shown in simplified form here. Here we see positive correlation between brand positioning and social media which means that for every decisions regarding the following factors respondents use social media. The high correlation of V1, V5and V8 representing product features, competitor goods analysis, and market trend with values of $.557, .395$ and .453 suggest that customers are using social media more to know these information than the other factors ultimately having an positive influence on increasing brand positioning.

\begin{tabular}{|l|l|l|l|l|l|l|l|l|l|l|}
\hline \multicolumn{9}{|c|}{ Table 3: Correlation Analysis } \\
\hline $\begin{array}{l}\mathrm{N}=250 \\
\text { Sig=.000 }\end{array}$ & V1 & V2 & V3 & V4 & V5 & V6 & V7 & V8 & V9 & V10 \\
\hline $\begin{array}{l}\text { Brand } \\
\text { Positioning }\end{array}$ & $.557^{* *}$ & $.243^{* *}$ & .120 & $.140^{*}$ & $.395^{* *}$ & $.299^{* *}$ & $.230^{* *}$ & $.453^{* *}$ & $.160^{*}$ & $.355^{* *}$ \\
\hline
\end{tabular}

**. Correlation is significant at the 0.01 level (2-tailed).

*. Correlation is significant at the 0.05 level (2-tailed).

\subsubsection{Regression Analysis}

Regression analysis was used to find out the impact of independent variable i.e. social media on dependent variable i.e. brand positioning. From the model summary we found $\mathrm{R}$ and $\mathrm{R}$ square. Here, R represents simple correlation value of .750 indicating a high degree of correlation between social media and brand positioning. Next, we see $\mathrm{R}$ square, which is also called coefficient of determination value of .562 indicating approximately $56.2 \%$ variation in brand positioning can be explained by social media. The adjusted $\mathrm{R}$ square value provides a more authentic value of the predicted $\mathrm{R}$ square value of the population. This value is very close to $\mathrm{R}$ square value with a small difference of $0.018(.562-.544)$ representing only $1.8 \%$ variation in actual results if the model is applied to the population. From ANOVA, we see df for total is 249 (250-1) and as we have 10 factors representing one independent variable the residual degree of freedom is 239 (249-10). The $F$ value of 30.696 is the result of division between Mean Square Regression and Mean Square Residual which is highly significant indicating the independent variable i.e. social media has the ability to predict the dependent variable brand positioning. The $\mathrm{P}$ value $(0.000)$ is less than the alpha level of 0.05 suggesting a statistically significant relationship between social media and brand positioning. From coefficient table, we found the ability of each factors of independent variable to predict the dependent variable. Here, $\mathrm{B}$ values show a positive relationship between social media and brand positioning. These are unstandardized coefficients because of measurement in normal units. For example, for each unit increase in product feature would predict .101 variance in brand positioning. The beta values are standardized coefficients of $\mathrm{B}$. The predictors with higher $\mathrm{t}$ values and lower significant values have the greater contribution in predicting dependent variables. Here, product features, competitors analysis and market trend have the greater predictability. Thus, all of the results suggest a significant relationship between dependent variable and independent variable accepting our hypothesis of "Social Media has a positive influence on Brand Positioning". 
Table 4: Regression Analysis

Model Summary

\begin{tabular}{l|c|r|r|r|r|r}
\hline Model & R & \multicolumn{1}{c|}{ R Square } & \multicolumn{2}{c}{ Adjusted R Square } & \multicolumn{2}{c}{ Std. Error of the Estimate } \\
\hline 1 & $.750 \mathrm{a}$ & .562 & \multicolumn{2}{c}{.544} & .38303 \\
\hline \multicolumn{7}{l}{} \\
\hline \multicolumn{2}{l}{ Model } & \multicolumn{7}{c}{ ANOVAa } \\
\hline \multirow{2}{*}{1} & Regression & Sum of Squares & Df & Mean Square & F & \multicolumn{2}{c}{ Sig. } \\
\cline { 2 - 8 } & Residual & 45.035 & 10 & 4.504 & 30.696 & $.000 \mathrm{~b}$ \\
\cline { 2 - 8 } & Total & 35.065 & 239 & .147 & & \\
\hline
\end{tabular}

Predictors: (Constant), High Pricing, Benefits, Brand Name, Competitors Analysis, Packaging, Customer

Expectation, Price Sensitivity, Market Trend, Product Features, Good Value Proposition

Coefficientsa

\begin{tabular}{|c|c|c|c|c|c|c|}
\hline \multirow{2}{*}{\multicolumn{2}{|c|}{ Model }} & \multicolumn{2}{|c|}{$\begin{array}{l}\text { Unstandardized } \\
\text { Coefficients }\end{array}$} & \multirow{2}{*}{$\begin{array}{c}\begin{array}{c}\text { Standardized } \\
\text { Coefficients }\end{array} \\
\text { Beta }\end{array}$} & \multirow[t]{2}{*}{$\mathrm{t}$} & \multirow[t]{2}{*}{ Sig. } \\
\hline & & $\mathrm{B}$ & Std. Error & & & \\
\hline \multirow[t]{11}{*}{1} & (Constant) & .993 & .183 & & 5.435 & .000 \\
\hline & Product Features & .101 & .030 & .182 & 3.326 & .001 \\
\hline & Benefits & .007 & .035 & .012 & .198 & .843 \\
\hline & Customer Expectation & .005 & .026 & .009 & .196 & .845 \\
\hline & Price Sensitivity & .062 & .026 & .113 & 2.376 & .018 \\
\hline & Competitors Analysis & .132 & .027 & .241 & 4.836 & .000 \\
\hline & $\begin{array}{ll}\text { Good } & \text { Value } \\
\text { Proposition } & \\
\end{array}$ & .111 & .036 & .184 & 3.077 & .002 \\
\hline & Brand Name & .064 & .027 & .110 & 2.406 & .017 \\
\hline & Market Trend & .144 & .029 & .251 & 4.945 & .000 \\
\hline & Packaging & .078 & .031 & .114 & 2.509 & .013 \\
\hline & High Pricing & .079 & .034 & .120 & 2.311 & .022 \\
\hline
\end{tabular}

\subsection{Testing of hypothesis 2: Social Media has a positive influence on Brand Equity.}

\subsubsection{Reliability Analysis}

As we know a thumb rule for reliability analysis is the value close to 1 is always better, thus our value of .751 including all items suggest a good reliability of this study with in every perspectives.

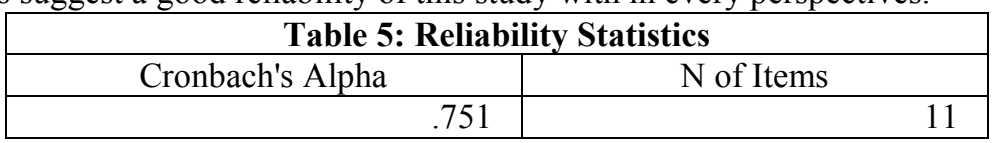

\subsubsection{Correlation Analysis}

From correlation analysis we see that every predictors of independent variable i.e. social media has a positive relationship with dependent variable i.e. brand equity. Here, we see that V14, V15 and V19 have the higher values than other predictors. V14 represents personality with a value of $54.5 \%$, V15 represents perceived value with a value of $45.6 \%$ and V19 represents behaviors of intermediaries with a value of $54.9 \%$. All of these has a good correlation with brand equity and customers are using social media platform to take decisions related with these factors.

\begin{tabular}{|l|l|l|l|l|l|l|l|l|l|l|l|}
\hline \multicolumn{10}{|c|}{ Table 6: Correlation Analysis } \\
\hline $\begin{array}{l}\mathrm{N}=250 \\
\mathrm{Sig}=.000\end{array}$ & $\mathrm{~V} 11$ & $\mathrm{~V} 12$ & $\mathrm{~V} 13$ & $\mathrm{~V} 14$ & $\mathrm{~V} 15$ & $\mathrm{~V} 16$ & $\mathrm{~V} 17$ & $\mathrm{~V} 18$ & $\mathrm{~V} 19$ & $\mathrm{~V} 20$ \\
\hline Brand Equity & $.292^{* *}$ & $284^{* *}$ & $.403^{* *}$ & $.544^{* *}$ & $.456^{* *}$ & $.320^{* *}$ & $.313^{* *}$ & $.371^{* *}$ & $.549^{* *}$ &. $.334^{* *}$ \\
\hline
\end{tabular}

\subsubsection{Regression Analysis}

From the regression analysis, we found $\mathrm{R}$ with a value of .761, which means a good correlation between dependent and independent variables. That means, about $76.1 \%$ change in dependent variable can be explained by the independent variable. Then, the $\mathrm{R}$ square value of .580 suggests the $58 \%$ variation is brand equity has been explained by predictors of independent variable. That means, if the value of independent variable changes by one unit then brand equity will be changed by $58 \%$. And the difference between adjusted R square and R square is $1.8 \%$ $(.580-.562)$ which very minor indicating a small difference in the actual result of total population. From ANOVA 
the $\mathrm{F}$ ratio is 32.971 with a table value less than $0.05(0.000)$ suggest that the model is highly significant to predict the dependent variable. The coefficients shows the relationship of each predictors of independent variable with dependent variable. Here we found that personality, perceived values and behavior of intermediaries have the higher $t$ value and lower significance level than others suggesting strong ability to predict dependent variable. Thus from all dimensions our results suggest to accept the hypothesis 2 i.e. Social Media has a positive influence on Brand Equity.

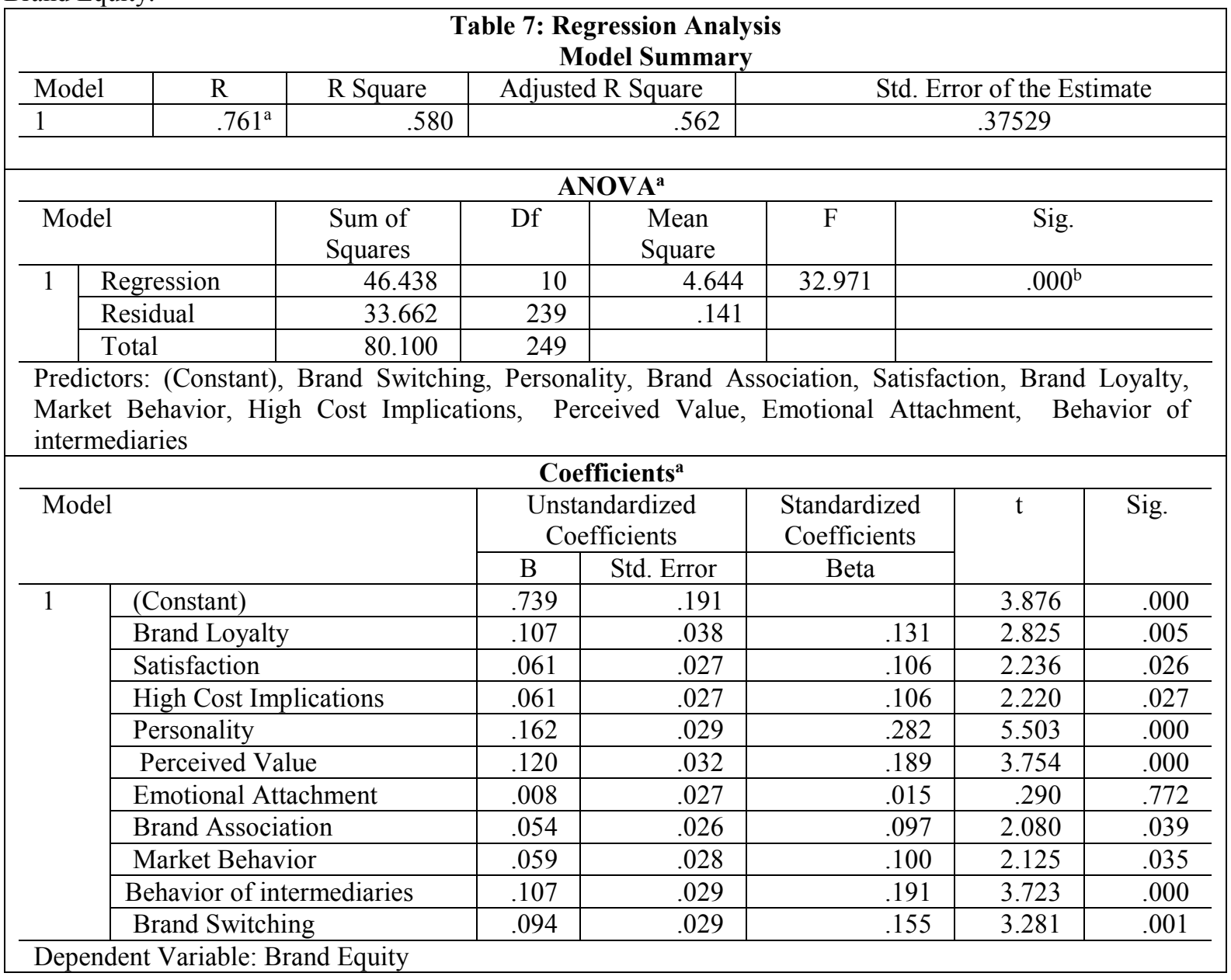

\section{Conclusion and Recommendation}

From the findings of revised literature we found that there are a lots of research studies on branding and social media. But in a developing country like Bangladesh where the users of social media are increasing gradually and online business, online shopping is also gaining popularity, we found limited research regarding social media marketing and investment in this sector. From these perspectives this research article is pioneering because there are few research on social media in our country but no research on its relationship with brand positioning and brand equity. To address this research gap two hypotheses were developed and tested. From the results we found that people are using social media as a platform of meeting their questions regarding any product or service, they found it as a easy way of communicating with marketing experts of different organizations as well as with other consumers of the same products. We also found a strong influence of social media on brand equity and brand positioning. Consumers are being dependent on social media to know about product features, discounts, price, offers from other competitive goods, new brands, product quality and performance, market trend etc. Although, it is not possible to attain loyalty towards a brand by social media marketing but from this study it can be seen that the social media can be used a platform to create brand awareness, association, emotional attachment towards a brand which can ultimately strengthen brand equity by creating a strong brand position. This study is expected to develop awareness among decision makers of business organization regarding social media investment. Further research can be conducted on social media investment by organizations, its impact on sales as well as on profitability including a larger size of population.

\section{References}

1. Aaker, D. (1991). Managing Brand Equity: Capitilazing on the Value of a Brand Name. New York, The Free 
Press.

2. Alhaddad, A.A.(2015). The Effect of Advertising Awareness on Brand Equity in Social Media. International Journal of e-Education, e-Business, e-Management and e-Learning, 5 (2),73-84, doi: 10.17706/ijeeee.2015.5.2.73-84.

3. Assael, H. (2001). Consumer Behavior and Marketing Action (6th ed.).Boston, MA., Thomson Learning.

4. Blackshaw, P., \& Nazzaro, M. (2004). Consumer-Generated Media (CGM) 101: Word-of-mouth in the age of the Web-fortified consumer. Retrieved from http://www.nielsenbuzzMetrics.com/whitepapers.

5. Brown, G. (1992). People, Brands and Advertising. - Millward Brown International, New York.

6. Christodoulides, G., \& Chernatony, L. (2010). Consumer based brand equity conceptualization and measurement. International Journal of Market Research, 52, 43-66.

7. Ceyhan,A.(2019). The Impact of Perception Related Social Media Marketing Applications on Consumers' Brand Loyalty and Purchase Intention. Emerging Markets Journal,9(1),88-100. dOI 10.5195/emaj.2019.173.

8. Davis, S. M. (2000). Brand Asset Management. Driving Profi table Growth Trough Your Brands, JosseyBass Inc, San Francisco .

9. Davis, S. and Bojalil Rébora, M. 2002. La marca: Máximo valor de su empresa. México: Pearson Educación.

10. Ellwood, I. (2009). Brand strategy, in: Brands and Branding, ed. R. Clifton, Profi le Books Ltd.

11. Gil, R. B., Andre's, E. F., \& Salinas, E. M. (2007). Family as a source of consumer-based brand equity. Journal of Product and Brand Management, 16(3), 188-199.

12. Gordhamer, S. (2009). 4 Ways Social Media is Changing Business. Retrieved from http://Mashable.Com/2009/09/22/Social-Media-Business/

13. Grubor, A.,Djokic, I. \& Milovanov, O. (2017). The influence of social media communication on brand equity: the evidence for environment friendly products. Applied ecology and environmental research, 15 (3),963-983.

14. Hoeffler, S., \& Keller, K. L. (2002). Building brand equity through corporate societal marketing. Journal of Public Policy \& Marketing, 21(1), 78-89.

15. Janiszewska, K. \& Insch,A. (2012). The strategic importance of brand positioning in the place brand concept: elements, structure and application capabilities. Journal of International Studies, 5 (1), 9-19.

16. Kaplan, A.M. and Haenlein, M. (2010) . Users of the World, Unite! The Challenges and Opportunities of Social Media.Business Horizons, 53, 59-68. https://doi.org/10.1016/j.bushor.2009.09.003

17. Keller, K. L. (1998). Strategic Brand Management: Building, Measuring, and Managing Brand Equity. New Jersey: Prentice Hall.

18. Keller, K. L. (2009). Building strong brands in a modern marketing communications environment. Journal of marketing communications, 15(2-3), 139-155.

19. Kotler, P., Keller, K. L. (2012). Marketing management (14th ed.). New Jersey, Prentice Hall.

20. Kim, A. J., Ko, E. (2012). Do social media marketing activities enhance customer equity? An empirical study of luxury fashion brand. Journal of Business Research, 65(10), pp. 1480-1486.

21. Jakštè,L.Z. and Kuvykaitè, R. (2016). Conceptualizing the social media communication impact on consumer based brand equity, TRENDY EKONOMIKY A MANAGEMENTU TRENDS ECONOMICS AND MANAGEMENT,25(1),68-74, DOI: http://dx.doi.org/10.13164/trends.2016.25.68

22. Mangold, W.G. and Faulds, D.J. (2009). Social Media: The New Hybrid Element of the Promotion Mix. Business Horizons , 52, 357-365. https://doi.org/10.1016/j.bushor.2009.03.002

23. McKinsey (2007). How Businesses Are Using Web 2.0: A McKinsey Global Sur-vey. The McKinsey Quarterly.

24. Mohsin, M. (2009). Encyclopaedia of brand equity management. Mumbai [India]: Himalaya Pub. House

25. Montero Torres, R. (2015). Las Redes Sociales en la Empresa. IT Campus Academy.

26. Neti, S. (2011). Social media and its role in marketing. International Journal of Enterprise Computing and Business Systems, 1(2), 1-15.

27. Nisar, T. M. and Whitehead, C. (2016). Brand Interactions and Social Media: Enhancing User Loyalty Through Social Networking Sites. Computers in Human Behavior, 62: 743-753.

28. Pozin, I. (2014). [Web page] Small Business Expert: Answers To Your Five Biggest Social Media Branding Questions. $\quad$ Forbes. $\quad$ Ref. 28 Nov. 2019]. Available at: http://www.forbes.com/sites/ilyapozin/2014/11/07/small-business-expert-an-swers-to-your-five-biggestsocial-media-branding-questions/

29. Schivinski, B., Dąbrowski, D. (2013). The impact of brand communication on brand equity dimensions and brand purchase intention through facebook. GUT FME Working Paper Series A. Gdansk (Poland): Gdansk University of Technology, Faculty of Management and Economics, 4, 1-24.

30. Tuominen, P. (1999): Managing brand equity. - The Finnish. Journal of Business Economics, 48 (1), 65-100.

31. Wheeler, Alina (2012). Design Brand Identity: an essential guide for the whole branding team. 3rd ed Electronic Data - New York: Bookman. 